\title{
ESPAÇOS COMPARTILHADOS E PRÁTICAS VIVIDAS: CARTOGRAFIA SOCIAL E ESPAÇOS DE MOBILIZAÇÃO DO BAIRRO DE SANTO AMARO - RECIFE/PE.
}

\author{
Vânia Fialho ${ }^{1}$ \\ Maria Jaidene Pires $^{2}$ \\ Rita de Cássia Maria Neves ${ }^{3}$ \\ Emmerson Pereira da Silva ${ }^{4}$ \\ Maria Marluce S. Gomes da Silva ${ }^{5}$
}

\section{Introdução}

Esse artigo é resultado de uma pesquisa multidisciplinar que teve como objetivo contribuir para a compreensão das questões sociais urbanas que associam as unidades de mobilização às motivações de cunho identitário. Trata-se, portanto, de uma proposta que se apropria da categoria "espaço" para identificar os lugares de socialização da comunidade de Santo Amaro, a fim de conhecer o seu potencial de mobilização política possibilitando subsidiar futuras intervenções de políticas públicas pautadas na sua realidade ${ }^{6}$

Diante do problema da estigmatização e do insucesso de políticas públicas em Santo Amaro, um bairro da cidade do Recife, capital do Estado de Pernambuco que se localiza no nordeste brasileiro, este trabalho possibilitou visualizar o potencial de mobilização e identificar as ações que vêm sendo efetivadas pelos moradores de Santo Amaro para suplantar o preconceito que recai sobre os mesmos e lidar com os problemas estruturais que enfrentam no cotidiano.

A pesquisa nasceu da articulação com o Projeto Nova Cartografia Social, coordenado pelo Professor Alfredo Wagner Berno de Almeida e sediado na UEAM, que objetiva a produção de mapas elaborados pelos segmentos sociais envolvidos. Com uma metodologia participativa que estimula a atuação das comunidades, a Cartografia Social

\footnotetext{
${ }^{1}$ Universidade de Pernambuco, Brasil.

${ }^{2}$ Universidade de Pernambuco, Brasil.

${ }^{3}$ Universidade Federal do Rio Grande do Norte, Brasil.

${ }^{4}$ Universidade de Pernambuco, Brasil.

${ }^{5}$ Universidade de Pernambuco, Brasil.

${ }^{6}$ A pesquisa que originou esse artigo intitula-se "Práticas e Espaços Sociais: Uma cartografia dos espaços de mobilização do bairro de Santo Amaro - Recife/PE”, e ocorreu entre 2012 e 2014, com financiamento do CNPq. Projeto Universal.
} 
pretende levantar todos os tipos de problemas que assolam determinada área, assim também como identificar as potencialidades locais. No caso dessa pesquisa, foram realizadas oficinas de mapas, que consistem em reuniões livres, abertas a toda comunidade, onde se discutem temas importantes sobre a realidade local. Simultaneamente, através de um intenso trabalho de campo etnográfico no bairro, foram feitas imersões de cunho antropológico, com observações e trabalho de campo objetivando uma melhor compreensão da realidade.

\section{Os caminhos da pesquisa}

No período inicial da pesquisa, optamos por conhecer as unidades de mobilização através de duas estratégias: visitas iniciais e entrevistas. Esta foi a forma de acessarmos as unidades de mobilização já organizadas de maneira institucionalizada: associações de moradores, associações de esporte, lazer e recreação do bairro. Essa aproximação com a comunidade possibilitou o envolvimento de alguns representantes nas atividades propostas pelo projeto de pesquisa, tais como seminários, rodas de diálogos e oficinas. Nos seminários que organizamos prevíamos metodologicamente a participação de acadêmicos, gestores públicos e representantes de moradores do bairro.

Em paralelo, no intuito de conhecer as formas e atuação das organizações governamentais e não-governamentais em Santo Amaro, realizarmos pesquisa documental nas seguintes instituições: Secretaria de Desenvolvimento Social, Secretaria da Cidade, Unidade do Governo Presente em Santo Amaro, Prefeitura da Cidade do Recife.

Nos seminários, reuniões, rodas de diálogos, visitas e entrevistas que organizamos e participamos ao logo da pesquisa destacaram-se os movimentos em torno da regularização fundiária, com ênfase para o movimento de mulheres que tem exercido o protagonismo nas negociações com o Governo do Estado que se desdobrou na regularização fundiária da região denominada Ponte do Maduro, que inclui parte do bairro de Santo Amaro e envolve as ZEIS (Zonas especiais de interesse social) Santo Amaro e Ilha do Joaneiro. Porém, optamos pelo conceito de unidades de mobilização (Almeida, 2008), por considerar que poderíamos dar mais visibilidade às mobilizações comunitárias que, mesmo não organizadas formalmente, apresentam potencial de 
articulação dos moradores do bairro Santo Amaro, cujas atividades são perenes: 1) clubes e times de futebol; 2) grupos voltados para a cultura popular: quadrilhas juninas, blocos carnavalescos; 3) grupos de atividades econômicas alternativas.

Outra técnica de pesquisa que utilizamos foi a etnografia. As etnografias obedeceram duas fases, que foram definidas no desenvolvimento da pesquisa: de maneira exploratória, as primeiras experiências etnográficas procuraram descrever a dinâmica do bairro no seu cotidiano e assim, identificar as formas de mobilização comunitária ali presentes. Foi nessa fase que compreendemos o significado das mobilizações comunitárias acima descritas. Na segunda fase, foram objeto de investigação os espaços de socialização do bairro e já com foco em algumas categorias que se destacavam, foram priorizadas as dinâmicas das associações de esporte e lazer, os grupos de dança popular, os idosos, as crianças e os espaços de rituais religiosos de matriz africana. O período destinado à realização das etnografias se estendeu por um ano visando melhor compreender o bairro, as áreas de mobilização e as intervenções comunitárias.

Para esse artigo, apresentaremos a composição do bairro de Santo Amaro, os espaços de mobilização, as ações e principalmente focaremos no significado das mobilizações efetuadas a partir de clubes de futebol inseridos no bairro. Esses clubes possibilitam a interação de pessoas do bairro que atuam em várias instâncias e que nesse espaço se inter-relacionam de forma mais livre e menos burocrática, diferente do que ocorrem nos espaços de Associações de Moradores, Sindicatos e ONGs, por princípio mais institucionalizado.

\section{Fundamentação Teórica}

O local, que tomamos aqui como sinônimo de espaço, é sempre tratado como objeto real, que se impõe a nós, por seu caráter natural, por sua necessidade antropológica ou cognitiva, por sua duração (Bourdin, 2001). No entanto, reconhecendo a outra possibilidade posta pelo mesmo autor, adotamos o espaço como categoria de análise, através da qual podemos procurar a compreensão para questões presentes na sociedade. Consideramos, assim, o espaço e a possibilidade de definir seus limites relacionando-o às identidades e à coesão afetiva, ética e política dos grupos, "num jogo 
da diferença, que garante uma harmonia ao mesmo tempo em que relativiza o poder" (Barcellos, 1995).

Esse trabalho parte do pressuposto de que os espaços físicos constituem lócus de socialização e que o olhar cuidadoso sobre ele, a partir de um instrumental teórico e metodológico diversificado, pode dar visibilidade a aspectos ainda não percebidos das relações sociais.

A representação cartográfica é uma leitura particular da realidade plotada em um mapa. Nesse sentido, os mapas são territórios, e mais, são territórios em disputa em uma verdadeira guerra simbólica de mapas. Vianna (2009) faz referência à guerra simbólica de mapas para afirmar a disparidade que existe entre as formas de representação de uma comunidade realizada por agentes externos e aquelas realizadas pelos próprios sujeitos.

Ascerald e Coli (2008), ao situarem as várias iniciativas de mapeamento, apontam três principais razões para que possamos entender o crescente interesse pelo campo da cartografia associado às mais diferentes áreas de conhecimento:

$1^{\circ}$ ) a maior parte das informações utilizadas na formulação de políticas, seja referente à criminalidade, planejamento de uso do solo, saúde ambiental, conservação de habitat ou provisão de serviços sociais contém um componente espacial; $2^{\circ}$ ) a ampliação do uso de informações espaciais para todas as partes interessadas leva presumivelmente a uma melhor formulação de políticas; $3^{\circ}$ ) estas informações politicamente relacionadas podem ser analisadas e visualizadas espacialmente, e o produto resultante - em sua maioria, mapas - pode transmitir ideias de forma persuasiva e convencer as pessoas da importância destas ideias. (Ascerald \& Coli, 2008: 18-19).

Nossa opção foi a de adotar a perspectiva da cartografia social (Almeida, 1993). Nesta, o processo de inclusão dos grupos envolvidos é de especial interesse, partindo do pressuposto de que os sujeitos sociais são capazes de se familiarizar com a ideia do mapa e com o repertório de informação nele contido.

Com essa análise procuramos compreender que movimentos sociais e unidades de mobilização estão presentes no bairro de Santo Amaro e de que maneira esses, juntos a outros dispositivos (legais, institucionais e discursivos), se articulam à vida cotidiana de seus moradores e se projetam espacialmente. A ideia foi estabelecer uma primeira aproximação do potencial mobilizatório do bairro, o que possibilitou identificar as organizações e mobilizações das quais procuramos nos aproximar para realizar a 
cartografia social propriamente dita, estabelecida e descrita pelos moradores dos locais em questão.

Os mapas resultantes das oficinas de cartografia social, que foram realizados no percurso do projeto, inseriram na leitura dos componentes de localização, a vida dos moradores do lugar. Lugar passou, então, a ser uma categoria importante, "cujo sentido tem se firmado, no plano conceitual, a partir década de 1970 como um espaço percebido sentidos de lugar e as imagens de lugar, envolvendo a dimensão cultural-simbólica”. (Souza, 2013: 16-17).

Souza chama atenção para a importância do bairro como um espaço que merece ser cuidadosamente valorizado enquanto lugar, quando se refere a políticas públicas que pretendem ser participativas (Souza, 2013). Há necessidade de deixar de considerá-lo meramente a partir de critérios técnicos objetivos, tais como a distribuição espacial de características como renda ou carência infraestrutural, ou, ainda, tais como recortes da própria natureza, a exemplo das bacias e drenagens. Assim, ao considerar o bairro como um lugar, como um espaço físico vivido, há necessidade de entendê-lo como inserido no processo histórico de sua conformação, tendo como referência espaços mais amplos como a cidade.

A preocupação em analisar as representações cartográficas do bairro de Santo Amaro e sua relação com as mobilizações sociais ali vividas, impulsionou-nos numa digressão nos estudos sobre a cidade, num esforço interdisciplinar que envolveu a antropologia, a sociologia, o urbanismo, o direito, a educação física e a geografia.

As Teorias da Cidade, bem sistematizadas por Barbara Freitag (2012), logo indicaram que, para além das tendências e linhagens bem delineadas entre as Escolas Alemã, Francesa e Anglo-Saxônica, nosso trabalho se aproximou de uma vertente nada convencional, de Ronald Daus ${ }^{7}$, que além do recurso à literatura, passou a estudar as megacidades por meio de sua produção cinematográfica, de seus jornais e outros materiais coletados durante viagens. Obviamente, nossa pesquisa se encontrou geograficamente limitada numa escala que nada se compara à trabalhada por Daus, mas inspirou-nos a possibilidade de fazer uma leitura de Santo Amaro a partir dos tantos dados que acessamos sobre o bairro. Daus afirma que as metrópoles extraeuropeias não

\footnotetext{
${ }^{7}$ Daus é Professor universitário alemão de Estudos Românicos e de Estudos Culturais na Universidade Livre de Berlim. Introduziu novos objetos de estudo na ciência tradicional inovando em etnologia e sociologia nas áreas urbanas de povoamento humano e de arquitetura.
} 
poderiam continuar sendo estudadas a partir das categorias da sociologia e da economia urbana, que tiveram como base as metrópoles europeias e propõe, entre outras formas de análise, categorias de descrição, o uso de gravuras, fotos, dados estatísticos, representações teatrais de rua, carnaval, revistas em quadrinhos, fotonovelas, vídeos, filmes, etc. Há uma certa aproximação de Daus com os denominados "dados convergentes" da etnografia de Geertz (1997). Parecia uma perspectiva interessante: conhecer Santo Amaro a partir da conjunção de dados que íamos encontrando e construindo pelo caminho.

Esta foi a nossa opção: considerando nosso cotidiano na Universidade de Pernambuco, situada no bairro, foco de nossa análise, procuramos vivenciar inclusive todas as nossas sensações: medos, tensões, familiaridades que nos deixavam explorar o bairro em todas as suas contradições e congregar todas as informações sobre o mesmo que conseguíamos acessar. Priorizamos os espaços de socialização, nem meramente público, nem meramente privado, mas uma dimensão do espaço que vai além da questão arquitetônica, urbanística, geográfica. Trata-se da dimensão antropológica que Argier (2011: 188-189) se refere à cidade, em especial à rua, como espaço entre dois, a rua como intermediária entre a grande praça anônima e o lar doméstico. É exatamente nesse entre dois, instável, indefinido e, por conseguinte, dificilmente controlável, que buscamos perceber a relação das pessoas que vivem em Santo Amaro e o uso do seu espaço.

Ir além não significa propriamente negar a herança conceitual das ciências sociais e, para entender o bairro de Santo Amaro, inserido na problemática urbana, foi também necessário uma aproximação do que Weber afirma ser uma cidade ocidental, entendendo-a como constituída a partir da cidade feudal: introdução da lei da propriedade da terra, que permite compra e venda do solo, cidadãos economicamente independentes, constituindo uma pequena burguesia; usurpação do poder feudal (baseado na propriedade da terra).

Consideramos e compartilhamos dessa herança do espaço marcado pela comoditização do solo, ao mesmo tempo em que ressaltamos o caráter criativo, inventivo e peculiar das cidades africanas ou latinoamericanas. Argier (2011), reforçando o que já expusemos das ideias de Daus, afirma que não há, para as duas realidades citadas um modelo de cidade. Segundo eles, "75\% ou $80 \%$ da população 
vive num espaço pouco controlado, pouco visto, pouco conhecido, muito reduzido e precário na sua materialidade. Não quer dizer que seja anárquico, desordenado, apenas quer dizer que não o conhecemos muito bem”. (Argier, 2011: 185).

\section{Santo Amaro: Bairro e Comunidade}

Situado na região central da cidade de Recife, Santo Amaro faz parte do anel central da cidade, definido pelo Atlas de Desenvolvimento Humano da Cidade de Recife (2005) como a área localizada na parte leste da cidade concentrando as principais atividades de negócios, além da função residencial. Compreende o centro histórico da cidade e o centro expandido que, nos últimos anos, com investimento públicos e privados, ampliou-se tanto à oeste da Avenida Agamenon Magalhães, como ao sul, ao longo dos corredores viários dos bairros de Boa Viagem e Imbiribeira.

Santo Amaro é uma região de ocupação antiga da cidade que mescla a presença de comércio, serviços e residências de classe média e de baixa renda, cuja população marginalizada pela falta de acesso a serviços básicos é marcada pelos altos índices de violência urbana que se define como comunidade ou favela. O Instituto Brasileiro de Geografia e Estatística (IBGE 2010) apresenta na área conhecida de maneira geral como bairro de Santo Amaro, nove aglomerados subnormais, o que nos ajuda a perceber o seu perfil demográfico ${ }^{8}$.

Apesar de designar uma área extensa que envolve um contingente extremamente diversificado, a região definida para o nosso trabalho, é a que compreende as áreas mais densamente habitadas (Prefeitura da Cidade do Recife, 2005) e que coincidem com duas ZEIS, ou seja, duas zonas especiais de interesse social ${ }^{9}$. Trata-se da porção leste do bairro, conhecida como a população periférica, que habita da margem da Avenida

\footnotetext{
${ }^{8}$ A identificação dos Aglomerados Subnormais é feita com base nos seguintes critérios: a) Ocupação ilegal da terra, ou seja, construção em terrenos de propriedade alheia (pública ou particular) no momento atual ou em período recente (obtenção do título de propriedade do terreno há dez anos ou menos); e b) Possuir pelo menos uma das seguintes características: 1- urbanização fora dos padrões vigentes - refletido por vias de circulação estreitas e de alinhamento irregular, lotes de tamanhos e formas desiguais e construções não regularizadas por órgãos públicos; 2- precariedade de serviços públicos essenciais.

${ }^{9}$ De acordo com a Lei Municipal No 17511/2008 que revisa o Plano Diretor do Município do Recife , as Zonas Especiais de Interesse Social - ZEIS são áreas de assentamentos habitacionais de população de baixa renda, surgidos espontaneamente, existentes, consolidados ou propostos pelo Poder Público, onde haja possibilidade de urbanização e regularização fundiária e construção de habitação de interesse social.
} 
Agamenon Magalhães até a Avenida Cruz Cabugá e o entorno do Shopping Center Tacaruna, um dos maiores da cidade.

Durante anos, os outdoors presentes na Avenida Agamenon Magalhães encobriram o conjunto de casas humildes dos moradores daquela região, por serem tidas como poluidoras da imagem da cidade e principalmente por estarem ao lado de um shopping. A área compreendida entre as duas avenidas citadas - entrecortada também por uma das mais importantes vias da cidade, a Avenida Norte - é vista como área de guerra, não sendo aconselhável por ela passar em período noturno. A disputa de grupos pelo controle do tráfico de drogas no bairro tem alarmado e feito crescer os índices de violência.

O bairro de Santo Amaro, no ano de 2007, apresentava características sócioeconômicas que o colocam e a seus moradores numa das situações sociais mais críticas, apresentando um dos maiores índices de violência dos centros urbanos brasileiros. De acordo com dados do Instituto Brasileiro de Geografia e Estatística (2000) e do Atlas Recifense de Desenvolvimento Humano (2005), os municípios de Recife, Olinda e Jaboatão dos Guararapes somavam, juntas, $76 \%$ do total de homicídios de Pernambuco. Especificamente em Santo Amaro, segundo informações da Secretaria de Defesa Social do Estado Pernambuco, o número de assassinatos de jovens (15 a 24 anos) no bairro, nos três anos anteriores, havia aumentado 80\%. Essas características chamaram a atenção das instituições governamentais e não-governamentais, que incorporaram Santo Amaro no rol dos vários programas e ações. Atualmente, apesar de notificado o decréscimo desses números, Santo Amaro continua sendo conhecido por seus aspectos negativos e de vulnerabilidade social.

Devido à grande dimensão do bairro de Santo Amaro, nesse trabalho atuamos a partir de dois polos específicos: a) Santo Amaro: que corresponde, aproximadamente à ZEIS Santo Amaro e que envolve especificamente as comunidades de Ilha de Santa Terezinha, Campo do Onze e Vila dos Casados; b) João de Barros: a qual corresponde à comunidade de João de Barros.

A denominação de comunidade é utilizada no sentido de indicar certo grau de coesão e organização social capaz de diferenciá-la de outras e que justifica determinadas ações de caráter coletivo marcadas pela identidade daquele grupo social e que dão sentido à ideia de pertencimento ao mesmo. Assim, os moradores de Santo Amaro não 
só se identificam como de Santo Amaro, mas também como de Campo do Onze, de Santa Terezinha, etc.

O bairro, na perspectiva mais abrangente, da forma que é considerado para efeitos administrativos da cidade, localiza-se na Região Política Administrativa (RPA) 1, na microrregião 1.1, como podemos visualizar no mapa abaixo.

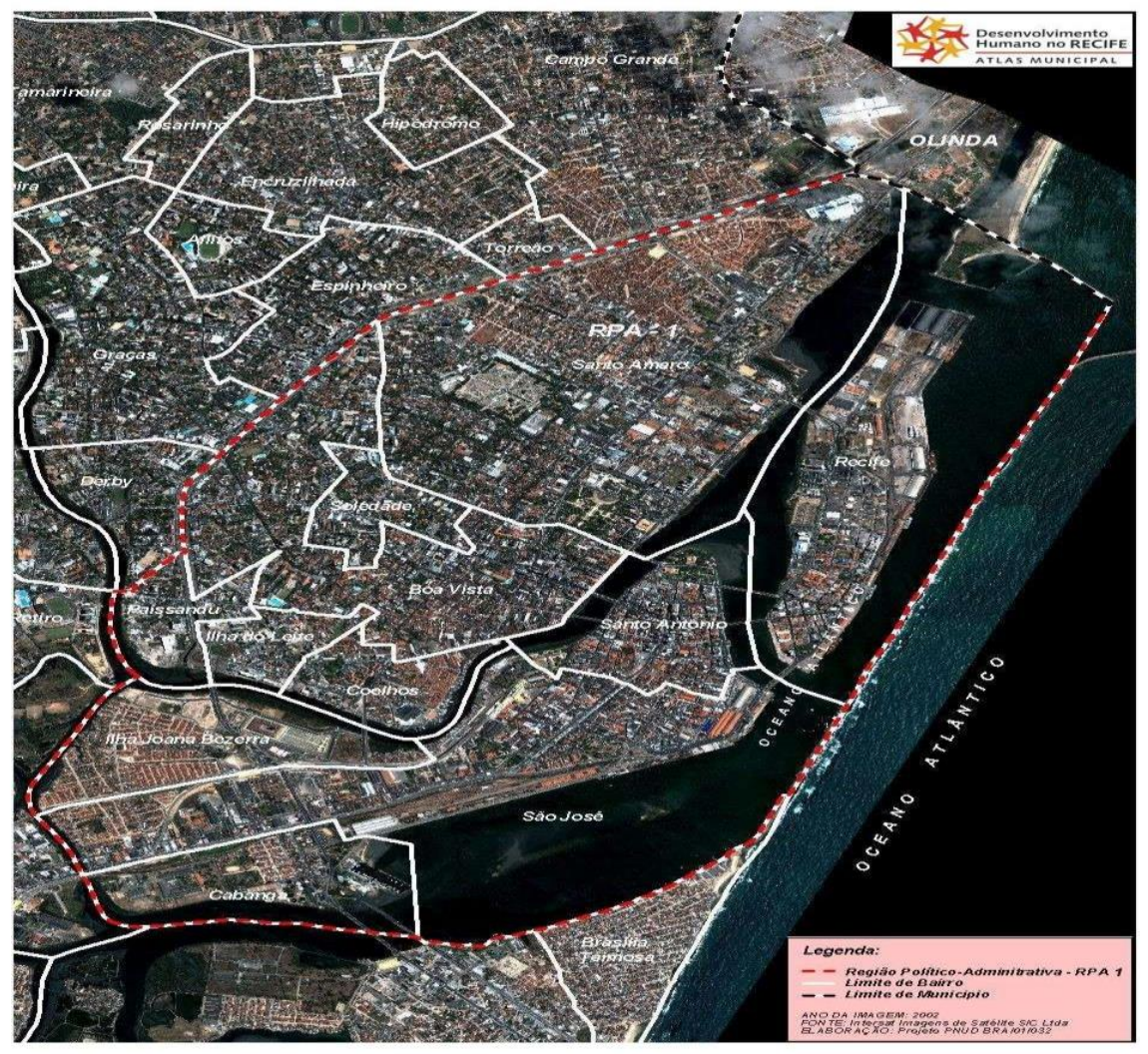

Fonte: Atlas do Desenvolvimento Humano do Recife, 2005

Salta aos olhos de qualquer transeunte no bairro de Santo Amaro o problema da desigualdade social. A questão da ocupação irregular dos terrenos associada à autoconstrução sempre foi a principal alternativa de acesso à moradia para a população de baixa renda no Recife e Santo Amaro é um exemplo desta situação. O recenseamento de 1913 já apontava que 43\% das unidades habitacionais do Recife eram caracterizadas como mocambos, o censo dos mocambos de 1939, revelou que quase metade da população do Recife, 164.837 habitantes, era constituída de mocambeiros e o levantamento realizado pela SEHAB - Secretaria Estadual de Habitação, em 19881989, referente aos assentamentos residenciais populares constatou que estes 
representavam 166.000 habitações, mais da metade dos domicílios na cidade do Recife que seriam levantados pelo censo de 1991 (305.901).

Atualmente, a população residente no Bairro é de 27.939 habitantes (CENSO IBGE, 2010), destes 12.680 são do sexo masculino (45,38\%) e 15.259 são do sexo feminino $(54,62 \%)$. E por faixa etária teremos o seguinte quadro:

\begin{tabular}{|c|c|c|}
\hline População por faixa etária & Habitantes & \% \\
\hline $\mathbf{0 - 4}$ anos & 1.745 & 6,25 \\
\hline $\mathbf{5}-\mathbf{1 4}$ anos & 4.404 & 15,76 \\
\hline $\mathbf{1 4}-\mathbf{1 7}$ anos & 1.468 & 5,25 \\
\hline $\mathbf{1 8}-\mathbf{2 4}$ anos & 3.471 & 12,42 \\
\hline $\mathbf{2 5}-\mathbf{5 9}$ anos & 13.258 & 47,45 \\
\hline $\mathbf{6 0}$ anos e mais & 3.593 & 12,87 \\
\hline
\end{tabular}

Fonte:http://www2.recife.pe.gov.br/a-cidade/perfil-dos-bairros/rpa1/santo-amaro/\#sthash.wpjQTNS5.dpuf

Santo Amaro tem uma densidade demográfica de 73,52 (habitante/hectare). Vale ressaltar que a proporção de mulheres responsáveis pelo domicílio é de 55,32\% (Censo, 2010).

Com relação à educação, a taxa de alfabetização da população de 10 anos ou mais é de 90,5\%, com uma taxa Média Geométrica de Crescimento Anual da População: 0,42\% (Censo, 2010).

O bairro conta com uma Universidade Estadual (Universidade de PernambucoUPE) e várias faculdades particulares, entre elas a Universidade Católica de Pernambuco-UNICAP, além de escolas da rede pública e particular. Santo Amaro tem como um dos locais de referência o Cemitério de Santo Amaro, além do Mercado Público de Santo Amaro, parques e praças que se constituem como espaços de sociabilidades.

Embora haja reclamações em relação aos serviços de saúde pública, o bairro de Santo Amaro conta com hospitais de referência, tais como: o Hospital Oswaldo Cruz, o PROCAPE e o Hospital do Câncer. É importante ressaltar que isso não quer dizer que a população do bairro tenha fácil acesso e seja bem atendida por esses serviços. Além disso, pela oferta de serviços esses dados contrastam, por esse bairro ser considerado pelo governo como composto por aglomerados subnormais. 
Dentro deste universo, as áreas densamente povoadas identificadas pelo Atlas da Cidade do Recife, correspondem aproximadamente às áreas com as quais estamos trabalhando. Nesta pesquisa, o território é definido como área de uma prática social, de um comportamento, de uma categoria social. É no interior desta região delimitada que os indivíduos desse grupo se sentem em afinidade.

\section{As Dinâmicas mobilizatórias em Santo Amaro}

Santo Amaro é formado por diferentes comunidades às quais correspondem diferentes territórios e que ora estão juntos para defender a maior barreira de luta dos moradores do bairro, que é a regularização fundiária do bairro, ora conseguem se separar em busca de uma identidade própria buscando mostrar sua diferenciação nos espaços territoriais.

Percebemos, no processo etnográfico, que os espaços de mobilização do bairro de Santo Amaro vão muito além daqueles que são oficiais, ou seja, quadras e campos esportivos. Uma pequena rua com pouca movimentação de carro pode se tornar um campo de futebol para as crianças jogarem. Os arredores de creches e escolas constituem locais onde as mães, que esperam seus filhos, se encontram, trocam informações, chegando a permanecer ali por mais de hora, conversando, trocando informações, ou seja em processos os mais diversos de socialização. As formas de manifestação cultural do bairro são também muito diversificadas.

A Fundação Do Patrimônio Histórico e Artístico de Pernambuco (FUNDARPE), em seu relatório do ano de 2010, intitulado Território Santo Amaro: patrimônios e potencialidade, identifica vários grupos e várias formas de mobilização do bairro, com seu histórico, localização, descreve também seus patrimônios, e, principalmente, como o bairro é organizado em grupos voltados para diferentes formas de expressão cultural, através dos grupos existentes como o Galpão dos Meninos e Meninas de Santo Amaro, Clube das Mães Santa Mônica, Centro de Desenvolvimento Renascer do Feitosa, Grupo de Hip Hop e de Grafitagem.

Estaremos destacando, neste momento, dois aspectos principais da mobilização de Santo Amaro: os espaços apropriados pelos seus moradores como lócus de socialização e a articulação e a presença do futebol, organizado em clubes que possuem uma 
importante atuação no bairro. A dinâmica dos clubes de futebol também proporciona a nossa compreensão do espaço de Santo Amaro, a partir do uso dos espaços oficiais e não oficiais para seus treinos e atividades e ainda refletem as relações de cooperação e tensão entre as comunidades que aqui definimos como constituintes de Santo Amaro.

A nossa pesquisa procurou identificar as práticas sociais dos próprios moradores, ao invés daquelas implementadas por organizações governamentais e nãogovernamentais. Em sua maioria são práticas que ainda não têm visibilidade e apoio financeiro, no entanto, têm viabilizado a transformação dessas práticas em ações de mobilização que asseguram a autoestima e se articulam com ações políticas de reconhecimento de identidades e de direitos.

Durante a pesquisa de campo, em que nosso olhar estava voltado para a identificação de associações envolvidas com atividades de cultura, lazer e recreação do bairro, nos deparamos com um número significativo de clubes de futebol no bairro, que desenvolvem atividades com crianças, adolescentes e adultos. Alguns desses clubes chegam a se destacar por já ter preparado jogadores que vieram a compor equipes profissionais de Pernambuco.

\section{Clubes de Futebol do Bairro de Santo Amaro}

\begin{tabular}{|c|c|}
\hline ASSOCIAÇÃO (CLUBE DE FUTEBOL) & COMUNIDADE DE SANTO AMARO \\
\hline 1 União Futebol Clube de Santo Amaro & Campo do Onze \\
\hline 2 Cruzeiro Futebol Clube & Campo do Onze \\
\hline 3 Alquaida de Santo Amaro & Campo do Onze \\
\hline 4 Central Esporte Clube & Campo do Onze \\
\hline 5 Havaí Esporte Clube & Campo do Onze \\
\hline 6 Vila Nova Esporte Clube & Campo do onze \\
\hline 7 Galáticos Futebol Clube & Campo do Onze \\
\hline 8 Central Esporte Clube & Campo do Onze \\
\hline 9 Soma Soma & Campo do Onze \\
\hline Amigos da Ilha de Santa Terezinha & Ilha Santa Terezinha \\
\hline 11 Paraguai & Ilha Santa Terezinha \\
\hline 12 Ajax Esporte Clube & Ilha Santa Terezinha \\
\hline 13 Cruzeirinho Futebol Clube & Ilha Santa Terezinha \\
\hline 14 Amigos Futebol Clube & Ilha Santa Terezinha \\
\hline 15 Bragantinho Futebol Clube & Ilha Santa Terezinha \\
\hline 16 Parma Futebol Clube & João de Barros \\
\hline 17 Palmeirinha Futebol Clube & João de Barros \\
\hline 18 Palmeiras & João de Barros \\
\hline Barcelombra Futebol Clube & João de Barros \\
\hline
\end{tabular}




\begin{tabular}{|c|c|}
\hline 20 Fluminense & Ilha de Janeiro \\
\hline 21 Flamengo & Ilha de Janeiro \\
\hline 22 Botafogo Esporte Clube & Vila dos Casados \\
\hline 23 Esperança Futebol Clube & Vila dos Casados \\
\hline 24 Corinthians & Rua Talar \\
\hline 25 Fora de Forma Futebol Clube & Santo Amaro \\
\hline 26 Os Miseráveis Futebol Clube & Santo Amaro \\
\hline 27 Juventude de Santo Amaro & Santo Amaro \\
\hline 28 Guerreiro Futebol Clube & Santo Amaro \\
\hline 29 Unibol Futebol Clube & Santo Amaro \\
\hline 30 Cinquenta e Um Futebol Clube & Santo Amaro \\
\hline 31 Viradinho Futebol Clube & Vila da Tecelagem \\
\hline
\end{tabular}

Inegavelmente, há no bairro a predominância das associações relacionadas ao futebol. Estas se mantêm com recursos próprios ou apoio político-partidário, o que em período de eleição passa a constituir um artifício de cooptação de lideranças. Essa prática é reforçada para se conseguir recursos e garantir a condição de uso dos espaços utilizados para as atividades dos clubes/times, pois esses são negligenciados pelo poder público. As praças, os campos de futebol e as quadras praticamente não recebem manutenção, embora salte aos olhos o fato do bairro possuir 31 times de futebol reconhecidos pelas comunidades.

Um aspecto muito interessante é o fato dos clubes de futebol refletirem a espacialidade do bairro organizado em diferentes comunidades. Foi percebido que as comunidades se articulam também em torno dos serviços a elas oferecidos e devido à carência de condições básicas de sobrevivência, grupos organizados em torno do tráfico de drogas controlam determinadas áreas do bairro. Como consequência, parte das tensões vivenciadas entre as comunidades são acirradas nas competições entre alguns times.

O que também percebemos é que os programas de esporte e lazer pouco utilizam o potencial organizativo do bairro. A intervenção do Estado, através do esporte, é pontual e não aproveita as dinâmicas de organização dos clubes de futebol para ampliar outras ações voltadas para a juventude, saúde e educação.

Sobre os demais espaços, a princípio não previstos como área de socialização pelos programas implementados, podemos identificá-los a partir do uso que os moradores já fazem deles. São eles: Ruas; Praças de grande circulação de pessoas de fora do bairro, onde os moradores de Santo Amaro organizam feiras de artesanato; 
Espaços de prática desportiva (sem manutenção) também utilizados por pessoas adultas e idosas para se encontrarem.

Os espaços de lazer, cultura, esporte e todos os espaços de mobilização social existem em grande número dentro do bairro, porém, assim como relatado, os espaços que possuem uma determinada estrutura para atender a comunidade também não contam com manutenção, pois a maioria desses espaços estruturados pertence ao poder público. Os moradores do bairro enfatizam em seus discursos que apesar da enorme variedade de objetivos de cada grupo, nas diversas áreas de atuação, há uma união dos moradores quando a causa é a luta pela regularização fundiária. $\mathrm{O}$ medo de perder $\mathrm{o}$ “bairro" é mobilizador, e isto é apontado com regularidade.

O bairro é muito bem localizado, vindo do centro da cidade é o primeiro bairro da zona norte do Recife. O crescente processo desenvolvimentista vivenciado nos últimos anos na cidade de Recife faz de Santo Amaro uma área de interesse para futuras especulações imobiliárias. Carla (40 anos), interlocutora na pesquisa, relatou em entrevista que "Aqui já é Boa Vista". O bairro também está na divisão do bairro da Boa Vista e da cidade de Olinda, sendo assim, na visão dos moradores, o foco no Bairro é a expansão imobiliária, que vem crescendo cada dia mais, com a chegada dos grandes empreendimentos no Recife. A localidade do bairro, as construções de novos edifícios, de condomínios fechados, pode vir a tomar conta de toda a área que Santo Amaro ocupa.

Os moradores também são muito críticos em relação à forma que a mídia trata o bairro. Na visão de Fernanda (30 anos), "a mídia mostra aquilo que ela quer mostrar"; a mídia não aborda todo o contexto do bairro. A maior parte das notícias levantadas no início do nosso estudo aponta que $99 \%$ dessas notícias divulgam aspectos negativos do bairro. Para exemplificar a fala da entrevistada e atualizar os dados da pesquisa, no levantamento feito com base no Jornal do Commercio, um dos mais importantes e influentes jornais escritos do Estado de Pernambuco, no primeiro semestre de 2012, de um total de 22 matérias que tratavam do bairro de Santo Amaro, apenas duas abordavam aspectos positivos do bairro; as demais abordavam questões relacionadas a crimes, violência e tráfico de drogas.

Não se pode negar os problemas que atingem Santo Amaro, mas é necessário enfatizar os mecanismos que seus próprios moradores têm elaborado, possibilitando que 
o conhecimento e a experiência do bairro sejam utilizados como aliados na definição de políticas e programas.

No mapa abaixo podemos identificar alguns dos espaços de socialização do bairro de Santo Amaro, como apontado por nossos interlocutores. Esses espaços são frequentemente utilizados pelos moradores e possuem maior potencialidade no seu uso. São áreas negligenciadas pelas ações propostas para o bairro, mas que são facilmente identificadas nas observações do seu cotidiano. Os espaços circunscritos na imagem estão sendo detalhadamente descritos e caracterizados quanto ao tipo de uso e da população usuária.

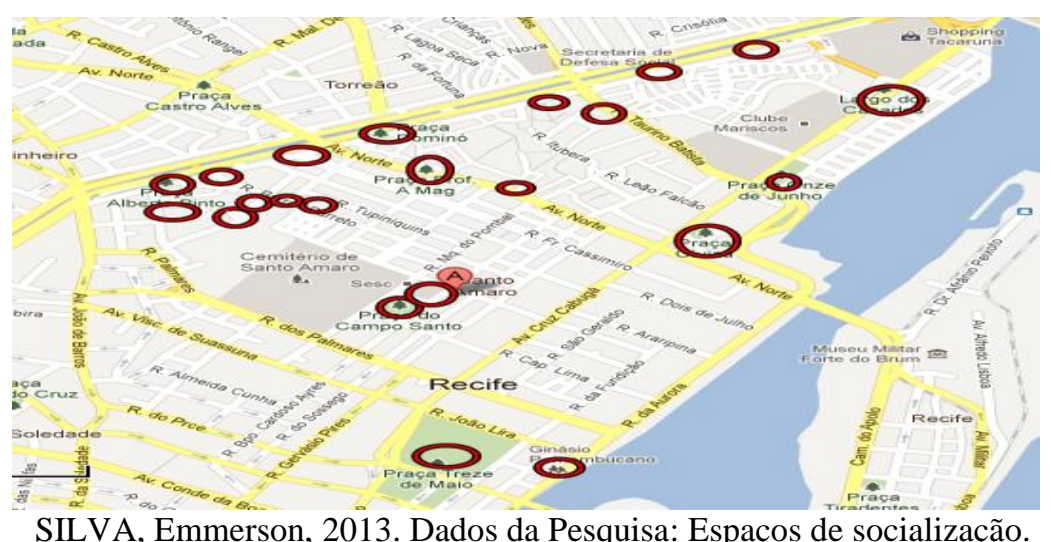

A partir de nossa observação, das entrevistas, oficinas e eventos que foram realizados em Santo Amaro, percebemos que há uma necessidade, seja por parte dos que atuam no bairro (ONGs, Universidades, Associações, etc), seja por parte do poder público (com ações sociais), de conhecer o bairro de perto e de dentro (Magnani, 2002), e de analisar suas práticas considerando noções sociológicas básicas, como diria Simmel (1983), de como a sociedade é “jogada” em Santo Amaro.

Os espaços de mobilização do bairro de Santo Amaro vão muito além daqueles que são oficiais; suas iniciativas são mais criativas e suas práticas sociais são muito mais efetivas do que aquelas elaboradas pelos doutos administradores.

Ao atentarmos para as categorias que se destacaram nas entrevistas, podemos perceber que a ênfase desses agentes que moram no bairro não é dada a partir de práticas assistencialistas, como se pressupõe erroneamente. O esporte e o lazer apontam para ações que vêm sendo coordenadas pelas próprias pessoas do bairro, 
principalmente, os times de futebol e que possuem um papel relevante no enfrentamento às questões consideradas fundamentais para os moradores do bairro.

As várias formas de mobilização social são sempre conjugadas com a ideia de constituir uma resistência à especulação imobiliária e de criar mecanismos de negociação com o Estado para efetivação da regularização fundiária do bairro. É também através desta mobilização que é criado um mesmo sentimento de pertença das diferentes comunidades que identificamos como integrantes do bairro. A desigualdade social propicia a elaboração de identidade baseada na diferença: Santo Amaro e ser de Santo Amaro cria também cumplicidades entre seus moradores; dentre elas, a de querer negar o caráter negativo propagado pela mídia.

A realidade com a qual estamos nos deparando nos permite fazer algumas afirmativas, ainda que transitórias: Há um imenso potencial de ação e organização desperdiçado no bairro de Santo Amaro, pouco aproveitado pelas organizações oficiais e até mesmo algumas ONGs; Há uma questão fundiária essencial, cuja solução é consenso para os moradores de Santo Amaro; Há, em todos, um desejo de ser reconhecido como sujeito de direitos e como cidadão e não como números ou índices estatísticos nos mapas do tráfico e da violência na cidade do Recife.

\section{Entrando e saindo do bairro}

Bairro? Onde começa e termina Santo Amaro? Como se constrói uma unidade de observação e análise a partir das práticas cotidianas?

Nossa entrada em Santo Amaro foi assim: já estávamos lá, a universidade, em que parte dos docentes da pesquisa trabalham, está encravada em Santo Amaro. Mas não se trata de uma relação do bairro como uma unidade político-administrativa do município. Trata-se de uma relação de sobreposição e disputas do que se compreende como espaço vivo e vivido (Braga \& outros, 2013). O bairro de Santo Amaro onde realizamos a pesquisa é compreendido pelo espaço das comunidades - como assim também se identificam - de baixa renda, que se distingue do seu entorno por uma identidade relacionada à pertença de um espaço que os situa social e economicamente à parte.

São várias as fronteiras, concretas ou imaginárias que conformam o que entendemos como Santo Amaro e também delimitam as comunidades que a compõem. 
Uma das estratégias que encontramos para começar a fazer a etnografia do espaço foi andar muito pelo bairro; entrar pelas ruelas, cruzar as grandes avenidas que o cortam. E, de fato, são grandes avenidas. O bairro é a periferia mais central que podemos encontrar na cidade do Recife. A avenida Norte, uma das mais importantes da cidade, que liga a zona norte ao centro, define os limites entre as comunidades de Santo Amaro e João de Barros. A avenida Agamenon Magalhães, que liga a zona sul à cidade de Olinda, representa o limite superior do bairro, separando-o de outras comunidades de baixa renda, que constituem outras duas zeis da cidade do Recife: Ilha do Joaneiro e Xié. Apesar da proximidade, não são concebidas como parte de Santo Amaro. Os limites entre as comunidades são marcados também pela geopolítica do tráfico de drogas e são frequentes os períodos em que nossas andanças não puderam ser realizadas pela tensão entre as gangues (Zaluar: 2012).

Em período de paz, procurávamos sempre utilizar camisetas que nos identificavam como sendo da universidade, era o nosso passe. Passe livre não só para nos identificar para as comunidades, como também para os policiais que, de tempos em tempos, realizavam os baculejos $^{10}$. Ficou também estabelecido entre nós que as visitas e as entrevistas seriam feitas em conjunto.

Inicialmente optamos por reuniões mais amplas realizadas nas dependências da universidade. Tratava-se também de uma iniciativa prevista no nosso projeto para possibilitar que além de nós acessarmos o cotidiano do bairro, as comunidades também pudessem acessar a universidade, visto que uma das críticas que ouvíamos com frequência era a distância entre a universidade e as comunidades do seu entorno. A primeira reunião foi realizada com a representação de associações do bairro. Algumas associações de moradores, outras de mães e mulheres e também associações esportivas.

Esta estratégia se tornou importante pois ao passo que ganhávamos a confiança dos moradores do bairro, permitiu também que realizássemos visitas às associações e identificássemos outras formas de associação.

Foi nesse processo que nos deparamos com a mobilização muito intensa no bairro em torno do futebol. Percebemos que o apelo que a prática do futebol tinha ia muito além do público atendido pelo Projeto Santo Amaro, chamado PSA, e que teve início no

\footnotetext{
${ }^{10}$ Como a comunidade nomeia as abordagens policiais.
} 
curso de Educação Física da UPE ${ }^{11}$. O contato com o cotidiano do bairro mostrou vários espaços dedicados à prática deste esporte: campos de areia, de chão batido e espaços que não conformavam exatamente um campo de futebol mas que eram utilizados para sua prática de maneira mais informal.

As primeiras conversas com Tito (liderança no bairro e funcionário da Prefeitura do Campus Santo Amaro/UPE), com Edvaldo (presidente da Associação de Moradores de João de Barros), com Marcondes (presidente do União Futebol Clube), com Doutor (liderança da comunidade de Santa Terezinha) e com seu Lula (liderança da comunidade de Santo Amaro) possibilitaram que identificássemos uma rede de articulação no bairro em torno dos campeonatos e das ações assumidos pelos times e clubes de futebol. Experiências de fundamental importância para entendermos a dinâmica do bairro foram os campeonatos realizados que já vinham sendo utilizados pelo governo do Estado dentro de suas ações do Programa Pacto pela Vida que objetivava a diminuição dos índices de criminalidade na cidade e a reconfiguração das relações entre as polícias e a população dos bairros.

Nesse sentido, ouvimos alguns relatos de iniciativas mal sucedidas, como no jogo ocorrido entre um time de Santo Amaro e outro formado por policiais militares que teria acabado com a reação destemperada de um policial, acirrando ainda mais o ânimo de ambas as partes; acompanhamos outro voltado para a celebração da paz, promovido pela Secretaria de Defesa Social e o Shopping Center Tacaruna.

Neste último, pudemos acompanhar a organização dede a formação das chaves, ou seja, dos grupos dos times que iriam se enfrentar. $\mathrm{O}$ curioso ficava pela impossibilidade de respeitar o sorteio caso alguns times, historicamente rivais, caíssem na mesma chave. Mecanismos de controle local, como novos sorteios, deveriam ser utilizados para viabilizar o campeonato. O horário representava outra característica peculiar: agendado para 15 horas, o início do primeiro campeonato que fomos assistir, nada começou antes das 18 horas. Antes disso, presenciamos um movimento intenso ao redor do campo de areia localizado às margens da avenida Agamenon Magalhães. Era um dia de sábado, chegamos por volta das 14 horas. Barracas ocupavam a calçada da via local, paralela à avenida citada, que dá acesso às casas das comunidades de Santa Terezinha. Algumas

\footnotetext{
${ }^{11}$ Projeto de extensão da UPE, que oferece atividades de esporte, saúde e apoio pedagógico para crianças e adolescentes de 07 a 17 anos.
} 
vendiam espetinhos (churrasquinhos) e bebida; outras frutas. Os integrantes dos times iam chegando aos poucos. Em meio à movimentação, também chegou a assistente social do Shopping Tacaruna, que desenvolve uma ação com os moradores dos arredores e alguns representantes da Secretaria de Segurança Pública. Na ocasião, éramos cinco da nossa equipe e acabamos sendo chamados para tirar fotografias com as autoridades, que registravam a iniciativa. Não sabíamos ao certo que posição tomar, pois estávamos no início da pesquisa e qualquer parcialidade poderia comprometer o restante do trabalho. Acabamos saindo às 17 horas sem assistir a abertura do campeonato, mas dessa forma difícil e atropelada demos início ao processo de cartografia social do futebol de Santo Amaro.

\section{A Cartografia Social do Futebol de Santo Amaro}

Realizar a cartografia do futebol no bairro de Santo Amaro em Recife foi uma tarefa que demandou bastante empenho, paciência e mesmo esforço da equipe.

A constatação inicial foi bastante surpreendente: a existência de mais de trinta times de futebol no bairro em atividade e que mobilizam homens, mulheres, crianças e adolescentes. Isto motivou a equipe de pesquisa a pesquisar a mobilização de moradores do bairro em torno deste esporte. Através do método "bola de neve" fomos identificando as lideranças e os responsáveis pelos times; a dificuldade se dava porque muitos deles não possuem sede e a sua localização se tornava uma verdadeira aventura dentro do bairro. Mas foi também essa busca que viabilizou o contato mais próximo com as comunidades que compõem Santo Amaro. Foram realizados inúmeros percursos etnográficos no bairro, assim também como aproveitamos a realização de campeonatos entre os times do bairro para melhor conhecer essa dinâmica e a relação identitária que existe entre os times/clubes e as comunidades de Santo Amaro.

De início, o acesso à comunidade, lideranças, presidentes de associação de moradores, times de futebol, só foi possível pela ajuda de uma liderança do bairro - Tito - que representava na ocasião o CONSUN - Conselho Universitário da UPE e que facilitou o nosso acesso junto à associação de moradores e outras lideranças. Fizemos uma reunião com eles na UPE, ocasião em que apresentamos o projeto que pretendíamos desenvolver no bairro. 
Foram inicialmente resistentes à ideia devido ao constante assédio de pesquisadores que após realizarem os seus estudos sequer voltam à comunidade para dar algum retorno. Mas seja pela inovação na temática, seja pela necessidade daquele momento de demandar uma série de melhorias nos espaços utilizados para a prática do futebol no bairro, houve o interesse em realizar a cartografia. Outra razão que muito contribuiu para iniciarmos o processo de articulação, foi a percepção por parte das lideranças das comunidades e dos times, de que uma das intenções do nosso estudo era propiciar uma releitura sobre a comunidade altamente estigmatizada pela mídia e desvelar a face criativa do bairro.

Tito continuou sendo para nós um intermediário entre nós e a comunidade, facilitando o nosso acesso às localidades de difícil acesso para estranhos. Ressalte-se também a habilidade com que Marluce Portela - a nossa bolsista de iniciação científica - facilitou a nossa aproximação com os times de futebol.

O previsto na metodologia do projeto era:

- Reunir a representação dos times de futebol para apresentar a Cartografia e definir, se fosse interesse deles, uma agenda de trabalho

- $\quad$ Fazer uma reunião preparatória para a oficina da Cartografia;

- Realizar a cartografia em um ou dois dias.

No processo nos deparamos com as seguintes dificuldades: impossibilidade de reunir todos os times num só local. Esta reunião foi esvaziada. Os presentes decidiram fazer várias reuniões próximas aos clubes, de modo a obter a anuência do maior número possível deles. Foram reuniões preparatórias nas comunidades Campo do Onze, João de Barros, Santa Terezinha e Santo Amato, no total de cinco; e a oficina de elaboração do mapa que se deu em três datas e mesmo assim não foi possível a participação de todos os clubes; Todas as falas da oficina foram gravadas e ficou decidido o que iríamos abordar na cartografia: A história do futebol no bairro de Santo Amaro; O mapeamento dos times de futebol do bairro; Os objetivos dos times de futebol; As dificuldades enfrentadas pelos times na realização do trabalho; O que gostariam de fazer.

Os mapas que dispúnhamos para servir de base continham erros (equipamentos sociais em ruas erradas, ruas onde se localizavam alguns clubes e campos de futebol inexistiam no mapa), o que demonstrava a imprecisão dos mapas oficiais. 
Foi resolvido na oficina preliminar, que os clubes e campos de futebol seriam georreferenciados com GPS pela bolsista e colaboradores do projeto de pesquisa da UPE em desenvolvimento no bairro e com o auxílio dos presidentes dos clubes, tornando possível marcar os pontos de localização deste. O mapa elaborado é parte importante da cartografia do futebol do bairro, possibilitando uma visão espacial mais concreta da presença desta atividade. De acordo com os representantes dos clubes, foi importante o trabalho da cartografia pois foi uma oportunidade de rever o trabalho realizado pelos clubes e dar visibilidade ao trabalho que vem sendo desenvolvido por estes, o que certamente ajudará na obtenção de recursos para melhor poder realizar o trabalho, assim como difundir essas informações para a comunidade recifense.

Abaixo apresentamos fragmentos do fascículo da Cartografia feita no bairro junto aos times de futebol, para melhor compreensão do processo intenso vivenciado pela equipe de pesquisa no bairro e, principalmente, para uma melhor compreensão do significado desses times para as pessoas de Santo Amaro:

\section{Fragmento da Cartografia Social dos Times de Futebol do Bairro de Santo Amaro.}

O bairro de Santo Amaro é conhecido como um dos bairros do Recife que mais se destacou e vem se destacando por possuir um grande número de times de futebol. Foi e continua sendo um celeiro de atletas, tendo muitos deles se destacado por vir a participar da seleção brasileira (Zequinha, Vavá, Rivaldo) e também de importantes clubes de futebol.

É... Marquinhos Paraná, na atualidade, Cassio no América, Kleber Sanatana que está no Havaí. Paulo Vitória de Santo Antão, Nino que está no CSA de Alagoa, Thiago Santos no América de Natal, ainda tem muito mais gente para lembrar ${ }^{12}$.

Atletas de Santo Amaro que passaram a jogar em outros clubes maiores:

12 As falas apresentadas não são identificadas porque é uma construção coletiva para o fascículo, aprovada pelo grupo. Embora tenham sido faladas nas oficinas de mapas pelos moradores, foram apropriadas como construção coletiva. 


\begin{tabular}{|c|c|}
\hline CLUBES & JOGADORES \\
\hline Clube Náutico Capibaribe & Gena, Douglas, Odacir, Gilvan \\
\hline Santa Cruz Futebol Clube & Rivaldo, Fernando Santana, Cabral, Vando, François \\
\hline Sport Clube do Recife & Rogério, Denor, Sandro, Parea \\
\hline Fortaleza Futebol Clube & Daniel \\
\hline América Futebol Clube do Recife & Marcos Costa, Cássio \\
\hline Confiança Futebol Clube - Sergipe & Válter Cardoso \\
\hline Central Futebol Clube - Caruaru & Cão, Santana \\
\hline Treze Futebol Clube-Campina Grande -PB & Wajneis \\
\hline Ibis Futebol Clube & Cadé \\
\hline América Futebol Clube - Natal & Thiago Sarita, Saulo \\
\hline CSA de Alagoas & Nino \\
\hline Alecrim de Natal & Môca \\
\hline Havaí - Santa Catarina & Kleber Santana \\
\hline
\end{tabular}

A existência de muitos times de futebol no bairro e o fato da maioria deles ter revelado talentos para o futebol profissional, fez com que o futebol de Santo Amaro fosse gradativamente conquistando o respeito dos times de futebol dos demais bairros do Recife.

vocês quando chegam nesses bairros a turma já tem um respeito porque é de Santo Amaro, é incrível isso, isso é em todo canto que a gente é ... Palmeirinha(clube) a gente passou por isso...se o time é de Santo Amaro, pode ser no bairro, no lugar que a gente chega, no interior que a gente chegar...

na época do nosso conhecimento das antigas que tem aqui, bota Ajax, 11 de Santo Amaro, vamos ver Ramesone, o Cruzeiro, o próprio Palmeirinha que já vem de outra geração, que significa a gente já pode analisar direitinho, é uma imensidão de time, de pessoas hoje que a gente passa. A gente vive nesse contato de futebol, como Marconi hoje que é um time em evolução, um sujeito que acompanha Cruzeirinho, Fora de Forma. 


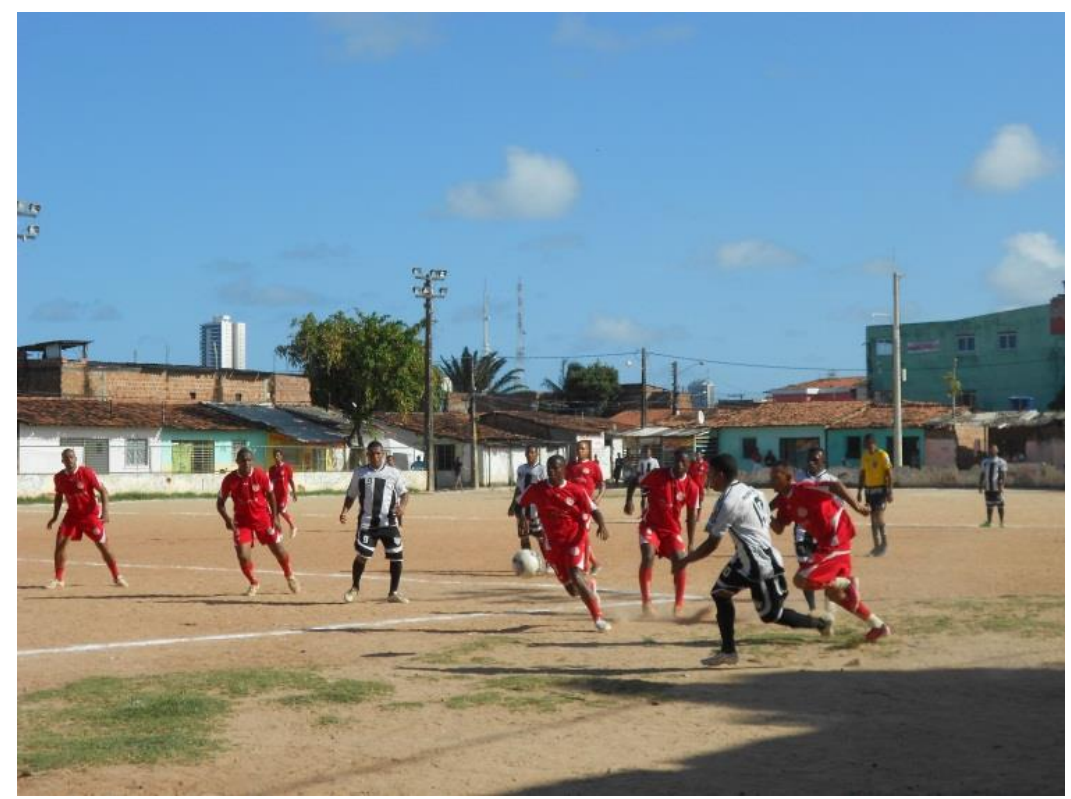

Foto campeonato Campo do Onze, 2014

Mesmo entre os clubes pernambucanos de maior tradição como o Náutico, o Sport e o Santa Cruz, o futebol de Santo Amaro é reconhecido e respeitado, pois as inúmeras escolinhas de futebol dos clubes do bairro fornecem às divisões de base destes e de outros clubes pernambucanos atletas que virão a se tornar profissionais.

Alguns clubes merecem destaque na história do futebol de Santo Amaro. Como exemplo, podemos citar o Ibis, um dos mais conhecidos e tradicionais do bairro, fundado em 15 de novembro de 1938, como meio de entretenimento para os trabalhadores da Fábrica de Tecelagem de Seda e Algodão de Pernambuco (TSAP). A princípio, apenas funcionários da empresa jogavam e mesmo assim eram partidas amistosas. Depois, o clube cresceu e se profissionalizou, tornando-se um dos clubes fundadores da Federação Pernambucana de Futebol. Com o passar do tempo e as dificuldades surgindo, o time foi abandonado pela TSAP e abraçado pela Família Ramos, que o mantém até hoje. O símbolo, a íbis sagrada do Egito antigo e a cor rubronegra,é uma referência ao escudo da TSAP. 


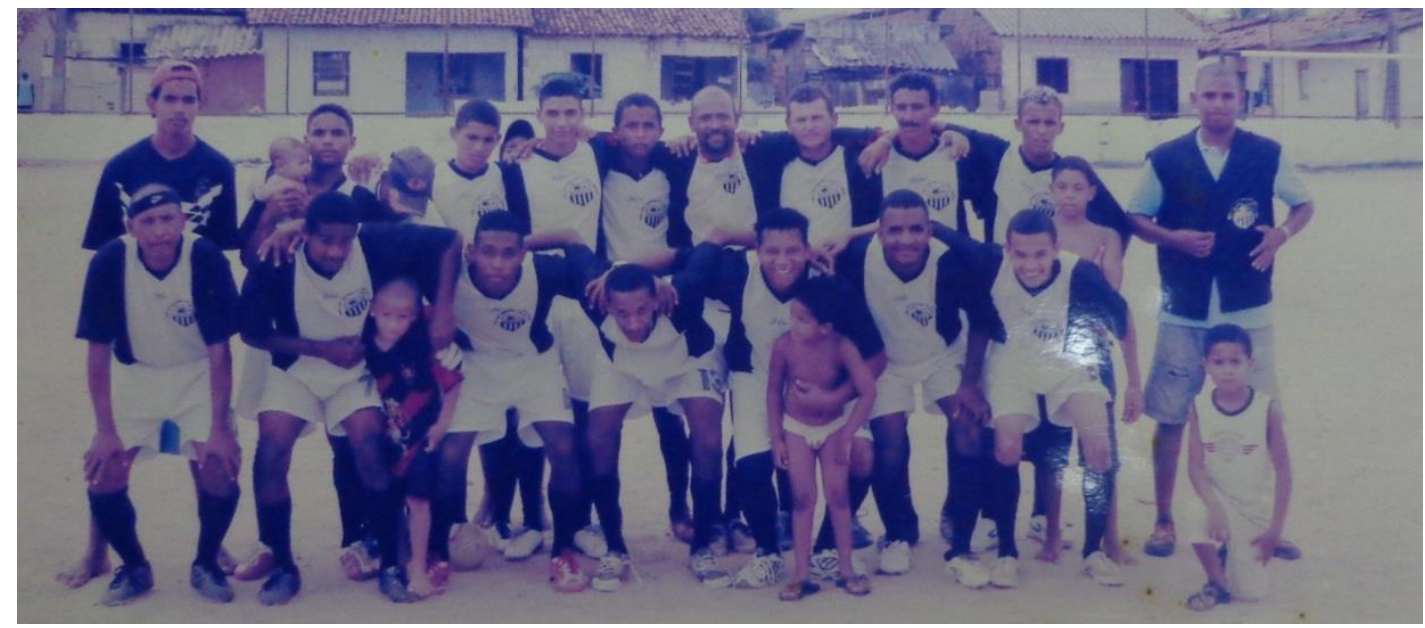

Foto arquivo da comunidade

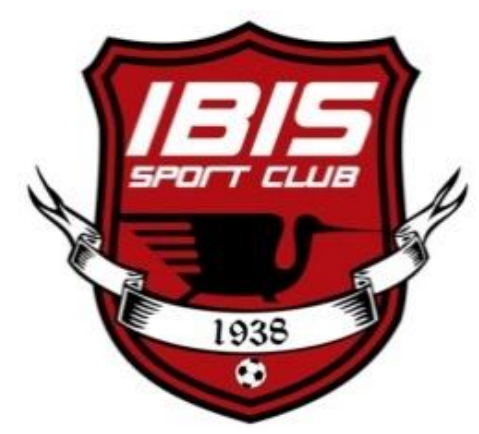

Simbolo do IBIS
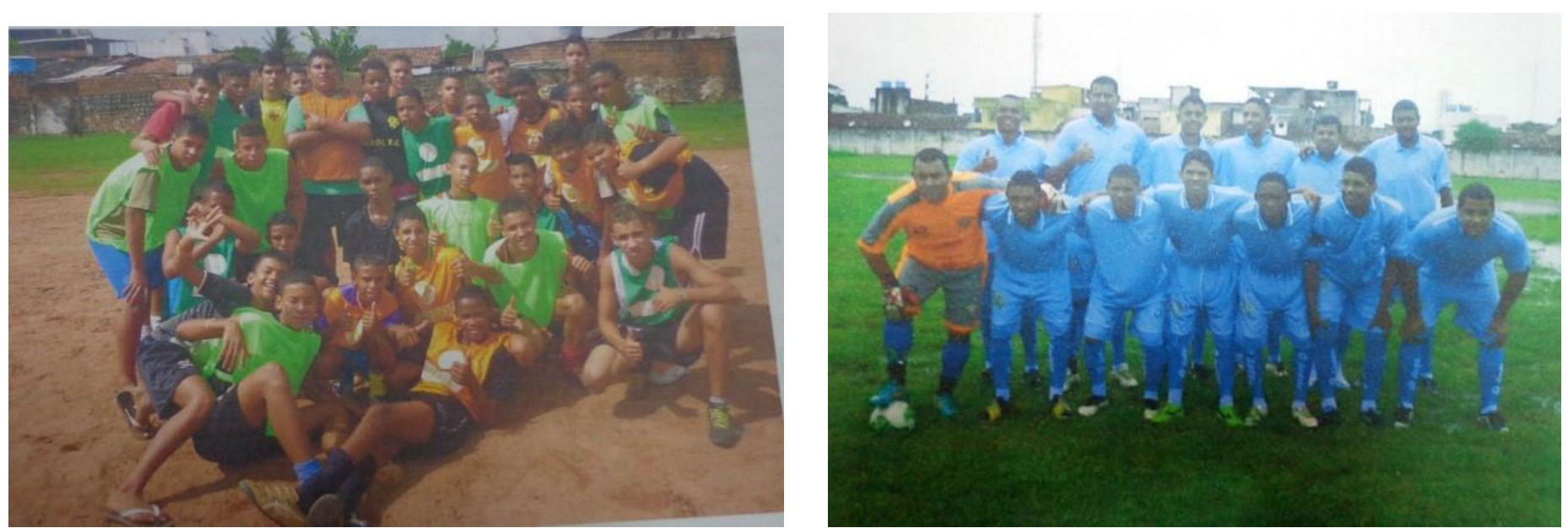

Foto arquivo da comunidade 

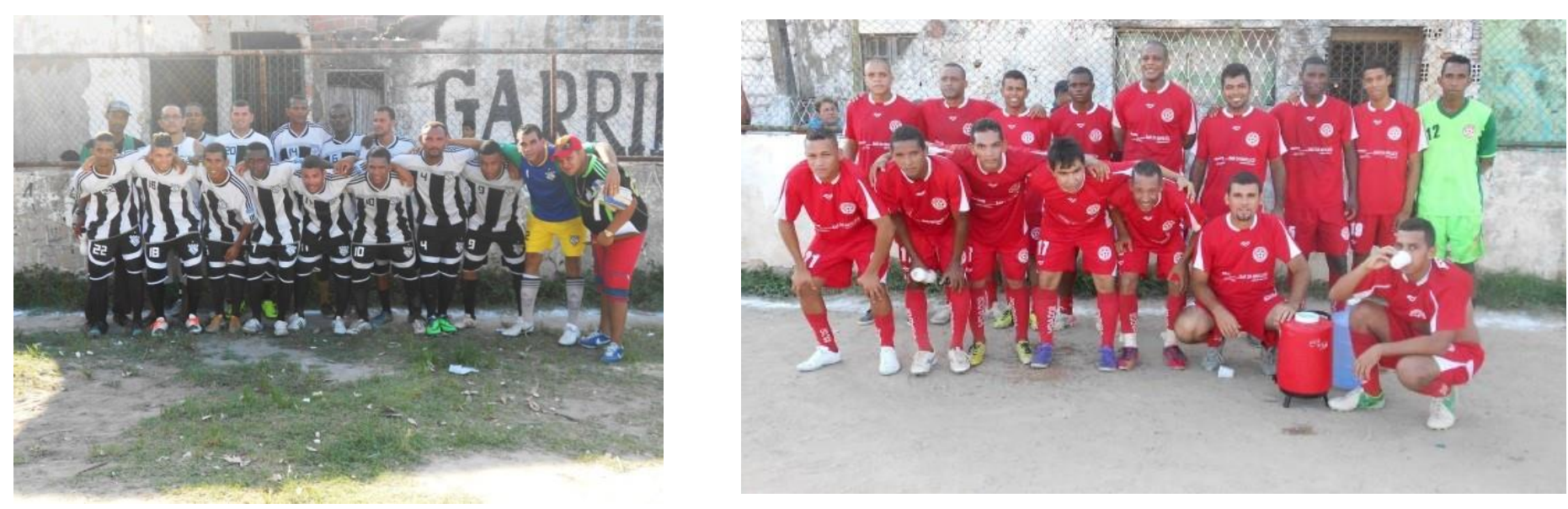

Foto arquivo da comunidade

Em relação aos objetivos dos times de futebol em Santo Amaro, a cartografia apontou que os times de futebol de Santo Amaro surgiram no bairro por iniciativa de pessoas que individualmente ou em pequenos grupos resolveram se juntar para jogar e desta forma atingir os seguintes objetivos: Propiciar lazer para os participantes; Fortalecer os vínculos de amizade; Disputar campeonatos; Tirar crianças, jovens e adultos da ociosidade; Propiciar às crianças e jovens a possibilidade de ingressar num clube de futebol; Afastar os participantes das drogas e da prostituição; Contribuir para que as crianças e adolescentes concluam a escolaridade básica; Contribuir com a formação social educativa e profissional das crianças e adolescentes; Projetar uma imagem positiva do bairro.

Tem crianças que se envolvem com drogas e a gente vai conversando e dando os exemplos de quem morreu e algumas saíram das drogas. ...perdemos muitos jovens para as drogas...

Nessa questão, eu tinha um amigo que jogava comigo no mesmo time que se envolveu com drogas, mas fomos conversando, alertando dando exemplos de outros que se envolveram e morreram ou estão presos. Daí, ele acabou conseguindo um emprego, voltando para o time, até hoje, e quando o vejo digo você poderia estar preso ou morto.

Nosso objetivo é de trabalhar com as crianças, formação social educativa e profissional.

Social: trabalhar com as crianças e acompanhar eles na família e na escola, ensinando o trabalho do dia a dia. No horário dos treinos as mães fícam despreocupadas.

Um dos nossos objetivos é de tirar o ranço de Santo Amaro, o estigma de Santo Amaro...fazer um bom time, crescer e dá exemplo para outros times, engrandecer o time a nível de bairro. O bairro de Santo Amaro tem um amor muito grande pelo futebol. 
nosso objetivo era tirar aquele estigma bem antiga contra Santo Amaro...queria fazer um novo modelo, que tínhamos recursos que vinham da dança, e nas reuniões das terças, fazíamos bondinhos, era aquela questão de clima de marginalidade, quando chegávamos sempre tinha: 'é de Santo Amaro, é?', sempre tinha aquela rivalidade, nosso objetivo era crescer, dar exemplo para outros fazerem a mesma coisa, daí surgiu mais time sobre isso.

Em resumo, Os clubes de futebol de Santo Amaro possuem duas linhas de frente: o objetivo de trabalhar formação social e educativa, a exemplo dos trabalhos com as crianças; e o objetivo de trabalhar a questão profissional, destacando os jogadores e times de Santo Amaro, dando uma visibilidade positiva para a comunidade, ou seja, trabalhar essa visão ruim do bairro, o trabalho que os times de Santo Amaro vêm fazendo e a valorização dos times a nível de base.

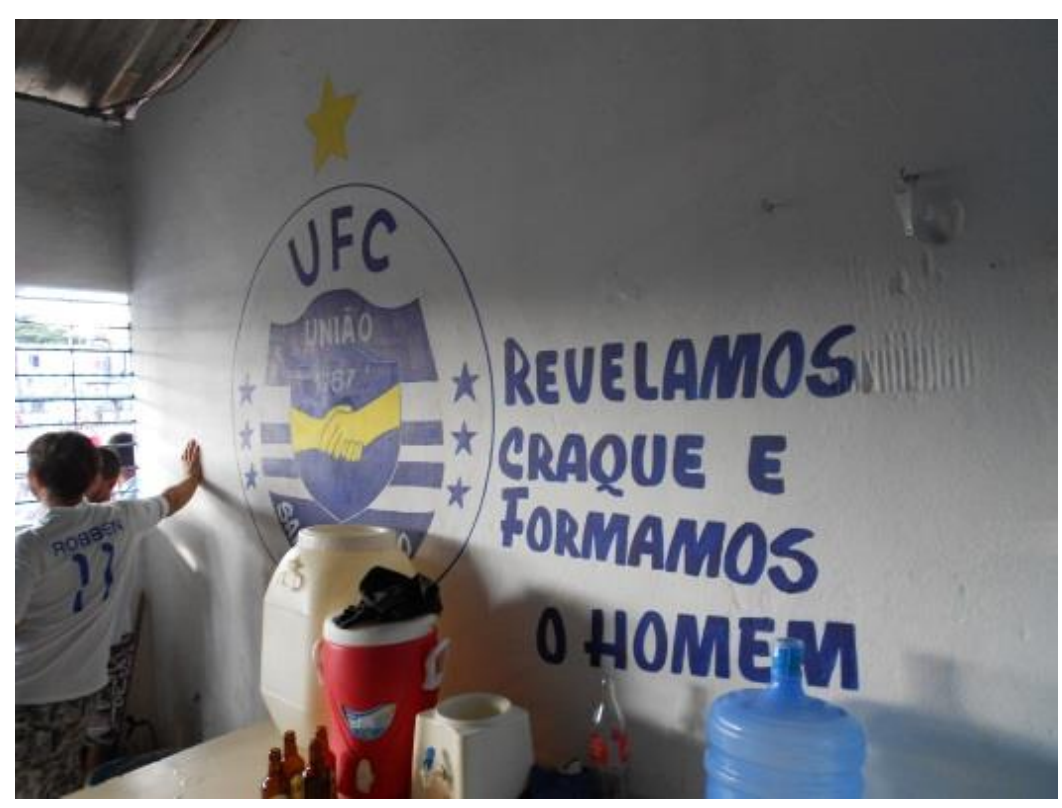

Foto: arquivo da pesquisa

\section{Dificuldades enfrentadas pelos times na realização do trabalho}

A maior dificuldade para os clubes e times de futebol de Santo Amaro é a dificuldade financeira. Em consequência, faltam recursos para tudo: compra de padrões de camisa, chuteiras, material esportivo. Quando há um campeonato, precisa-se de inscrever individualmente cada atleta, sendo necessário o pagamento de uma taxa; temse que providenciar lanche e transporte para os jogadores e acompanhantes. 
A grande maioria dos times não possui sede própria, sendo esta a residência do presidente do clube. Até mesmo o vestuário dos atletas muitas vezes é lavado pela mulher do presidente do clube. Este, muitas vezes põe dinheiro do seu próprio bolso, chegando a afetar o orçamento da família e causar conflitos.

É frequente a utilização de rifas, festas e outras estratégias para a obtenção dos meios necessários à realização do trabalho, isto sem contar com a mensalidade paga pelos dirigentes do clube. Na realidade, falta apoio tanto dos órgãos públicos quanto da iniciativa privada. É difícil conseguir dialogar com o poder público e os vereadores só comparecem em época de eleição. Nessa época, segundo relatos, eles dão um padrão de camisa e, quando passa a eleição, eles desaparecem.

Outra necessidade que merece destaque diz respeito aos campos onde treinar. Esses campos de várzea têm diminuído e os poucos campos que existem são precários. O Campo do Onze não possui vestiário. Os jogadores trocam de roupa nas barracas e casas de conhecidos na vizinhança, além de ser mal conservado.

Eu agora mesmo estou passando por uma situação, se volto ao campo da ESEF ou Campo do Onze, para voltar a Federação Pernambucana, esperando uma resposta. Fui convidado porque tinha um título da $3^{\mathrm{a}}$ divisão de amadores da capital e registrado isso. Estou com dificuldade nisso, em encontrar um campo para treinar, treinando não, um campo, daí estou com essa dificuldade.

Como podemos perceber, esses fragmentos do fascículo da Cartografia acima apresentados, ao mesmo tempo em que apontam para os problemas vivenciados pelos times de futebol do bairro, indicam o enorme potencial de mobilização.

\section{Tecendo Considerações}

Tendo por base apenas os dados socioeconômicos oficiais, o Governo do Estado de Pernambuco implementou uma série de iniciativas em Santo Amaro, visando o combate à violência e, para isso, investiu em projetos sociais, tentando atingir, principalmente, crianças e jovens. Como exemplo, podemos citar o programa "Governo Presente", que buscou capacitar os jovens em informática; montou cineclube e disponibilizou programas de esporte. 
As Organizações Não Governamentais (ONGs) tais como o Grupo "Ruas e Praças" e "Pé no Chão", desenvolveram ações com o mesmo objetivo, embora com ações diferentes.

No entanto, as políticas e programas ali implementados vêm sendo severamente criticados pelos moradores de Santo Amaro. Estes se queixam da verticalização das ações e da pouca importância dada pelos seus organizadores à necessidade de ouvir os próprios moradores e conhecer de forma mais efetiva seus anseios e características.

Como nossa atenção estava voltada para as representações cartográficas sobre o bairro e aquelas elaboradas pelos moradores do bairro, partimos da hipótese de que os projetos direcionados ao bairro não vinham sendo exitosos, na perspectiva dos moradores porque estavam baseadas em informações que não consideravam a concepção do bairro enquanto lugar, enquanto um espaço vivo e vivido.

No intuito de conhecer, inicialmente, o bairro através das várias formas que ele foi representado cartograficamente, empreendemos uma busca por mapas que, de alguma forma, falavam de Santo Amaro.

Encontramos mapas de períodos históricos diferentes, que vão desde o período da dominação holandesa, no século XVII, até os dias atuais, já compreendendo o bairro de Santo Amaro.

Podemos classificar os mapas nas seguintes categorias: 1) históricos; 2) de programas estatais; 3) de planejamento urbano; 4) de base demográfica. Nos mapas históricos, Santo Amaro é citado como componente do centro da cidade do Recife, área de ocupação mais antiga da cidade. Nos que se referem aos programas estatais, identificamos os relacionados a ações emergenciais e os de diagnósticos para embasar as ações governamentais. Nos mapas de planejamento urbano, encontram-se os mapas administrativos que indicam a organização político-administrativa da cidade. Denominamos os de base demográfica aqueles que estão baseados em dados censitários, coadunando espaço físico e situação socioeconômica de sua população.

Ao analisar os mapas coletados podemos constatar que o bairro de Santo Amaro, desde muito cedo, vem sendo retratado e se situa numa área importante para o processo de urbanização da cidade do Recife. Santo Amaro poderia ser entendido como um microcosmo a partir do qual seria possível entender como o espaço urbano se articula com os ciclos econômicos e as dinâmicas locais, regionais e nacionais. 
Os mapas produzidos nas oficinas de cartografia social indicaram aspectos interessantes e importantes: as informações são vivas e sensíveis. O protagonismo é assumido por categorias diversificadas; a mediação institucional é colocada em xeque. Os times de futebol, no processo da elaboração dos mapas, viveram uma digressão. Visitaram a memória do bairro e o importante papel que os times têm na dinâmica, na educação e na mobilidade social do bairro. Optaram por tratar a história do futebol no bairro de Santo Amaro; o mapeamento dos times de futebol do bairro; os objetivos dos times de futebol; as dificuldades enfrentadas pelos times na realização do trabalho; o que gostariam de fazer.

Um dos aspectos mais importantes que percebemos nesse processo é que o fascículo, produto resultante das oficinas, dá visibilidade para os espaços de socialização que são utilizados nas ações dos times de futebol.

Inegavelmente, há no bairro a predominância das associações relacionada ao futebol. Estas se mantêm com recursos próprios ou apoio político-partidário, o que em período de eleição passa a constituir um artifício de cooptação de lideranças. Essa prática é reforçada para se conseguir recursos garantir a condição de uso dos espaços utilizados para as atividades dos clubes/times, pois esses são negligenciados pelo poder público. As praças, os campos de futebol e as quadras praticamente não recebem manutenção.

Um aspecto muito interessante é o fato dos clubes de futebol refletirem a espacialidade do bairro organizado em diferentes comunidades. Foi percebido que as comunidades se articulam também em torno dos serviços a elas oferecidos e devido à carência de condições básicas de sobrevivência, grupos organizados em torno do tráfico de drogas controlam determinadas áreas do bairro. Como consequência, parte das tensões vivenciadas entre as comunidades são acirradas nas competições entre alguns times.

O que se percebe, por fim, é que os programas de esporte e lazer pouco utilizam o potencial organizativo do bairro. A intervenção do Estado, através do esporte, é pontual e não aproveita as dinâmicas de organização dos clubes de futebol para ampliar outras ações voltadas para a juventude, saúde e educação. 


\section{Referências}

ALMEIDA, Alfredo. Carajás: a guerra dos mapas. Belém: Editora Falangola. 1993

ASCERALD, Henri; COLI, Luiz Régis. Disputas territoriais e disputas cartográficas, in: Henri ASCERALD; Luiz Régis.COLI, (orgs.). Cartografias sociais e território. Rio de Janeiro: IPPUR/UFRJ. 2008, pág 13-44.

BARCELLOS, Jorge. Territórios do cotidiano: uma introdução a uma abordagem teórico contemporânea in: Zilá MESQUITA; Carlos BRANDÃO (orgs.). Territórios do cotidiano: uma introdução a novos olhares e experiências. Porto Alegre/ Santa Cruz do Sul: Editora Universidade/UFRGS/UNISC. 1995.

BARDIN, Laurence. Análise de conteúdo. Lisboa:.Edições 70. 1979.

BOURDIN, Alain. A questão local. Rio de Janeiro: Editora DP\&A. 2001

BRAGA, Ísis; FIALHO, Vânia; PIRES, Maria Jaidene; SILVA, Emmerson P.; SOUSA, Maria Marluce; VITAL, Felipe. Regularização do espaço vivo e vivido: a questão fundiária do bairro de Santo Amaro. Trabalho apresentado no XXXV Congresso Internacional de Americanística. Perugia, Itália, 2013.

FRANCO, Maria Laura. Análise de Conteúdo, Brasília: Liber Livro. 2008.

GOMES, Paulo. A condição urbana: ensaios de geopolítica da cidade. Rio de Janeiro: Bertrand Brasil. 2002.

MAGNANI, José. De Perto e de Dentro: notas para uma etnografia urbana. In: Revista Brasileira de Ciências Sociais, v. 49, jun. 2002.

MELUCCI, Alberto. A invenção do presente. Petrópolis: Editora Vozes, 2001.

MESQUITA, Zilá. Do território à consciência territorial, in: Zilá M. MESQUITA; Carlos Rodrigues BRANDÃO (Orgs.). Territórios do cotidiano. Porto Alegre: Ed. Universidade/ UFRGS/ UNISC. 1995.

PREFEITURA DA CIDADE DO RECIFE. Atlas do Desenvolvimento Humano no Recife. 2005.

SIMMEL Georg. Sociabilidade: um exemplo de sociologia pura ou formal. In: MORAES FILHO, Evaristo. Georg Simmel: sociologia. Petrópolis: Editora Vozes, Petrópolis. 1983.

VIANNA, Aurélio. O reencantamento da cartografia. In: Le Mondo Diplomatique, Jun. 2009.

ZALUAR, Alba. Pesquisando no perigo: Etnografias voluntárias e não acidentais. In: Mana (15) 2. 200. Pág. 557-584.

Recebido em: 25/09/2014 Aprovado em: 20/11/2014 